\title{
内圧作用下に打ける曲げ加工された銅配管の低サイクル疲労破壊現象
}

田宮 洋 一*

\section{Low-Cycle Fatigue Fracture Phenomenon of Bended Copper Pipes under Internal Pressure}

by

\author{
Yoichi TAmiYa *
}

\begin{abstract}
It is well known that fatigue strength of bended copper pipes under internal pressure is decreased by flattening and change in thickness at the cross section. It is important to understand fatigue fracture phenomenon of bended copper pipes, because they are significant members utilized in air-condition equipments and hot-water supply systems. In this paper, fatigue tests of bended copper pipe specimens were carried out under internal pressure and stress conditions of these cross sections were calculated by finite element method (FEM), in order to clarify fatigue fracture phenomenon of bended copper pipes.

The conclusions are obtained as follows :

(1) Origin of fatigue fracture of bended copper pipes was the same as position of maximum stress range $\left(\triangle S_{M A X}\right)$ obtained by FEM.

(2) In tested copper pipe specimens, $\Delta S_{M A X} / \Delta \sigma$ at the cross section was strongly affected by flattening ratio $\left(D_{o S} / D_{o L}\right)$, and $\Delta S_{M A X} / \Delta \sigma$ was less affected by change in thickness ratio $\left(T_{\text {out }} / T_{\text {in }}\right)$. Where, $\Delta \sigma$ is an elastic stress range of Lamé's equation.

(3) Fatigue fracture phenomenon of bended copper pipes under internal pressure was similar to low-cycle fatigue fracture phenomenon of strain controlled type at stress concentration parts.

Key words : Low-cycle fatigue, Fatigue fracture phenomenon, Bended copper pipes, Internal pressure, Stress concentration, Flattening, Change in thickness
\end{abstract}

\section{1 緒袞}

空調機や給湯機は圧縮機, 蒸発器, 膨張弁, 凝縮器お よび熱交換器などで構成されており, 各構成機器の間お よび内部には，冷媒を巡回させるための銅配管が縦横無 尽に配置されている。これら銅配管の構造は，直線部， 曲げ加工部扎よびロウ付継手部などが混在しており, 複 雑多岐にわたっている。このような配管構造の中で，曲 げ加工部は，曲げ変形による配管横断面の扁平・偏肉が 耐圧強度を低下させるので, 強度設計上の要注意部位で ある。

曲げ変形による配管横断面の扁平・偏肉が耐圧強度を 低下させることは, 古くから良く知られていた.1)〜3)特に， 扁平・偏肉による応力集中は, 疲労強度に対して顕著に 影響するので, 静圧破壊強度の低下よりも内圧疲労強度 の低下に注意しなければならない，現時点では，実際に 曲げ加工した配管試験片を用いて, 内圧疲労試験を実施 することで，その疲労強度を確認しているのが実情のよ うである. ${ }^{4) \sim 7) ~}$

近年, 環境破壊防止を目的として, $\mathrm{CO}_{2}$ 冷媒を採用し ている給湯機の普及や空調機の開発が進められている.8) $\mathrm{CO}_{2}$ 冷媒は, 従来の冷媒より高圧で作動するため, これ らの製品には高い信頼性が要求される。また製品である
限りは，低コスト化についても，今までど拈り市場から 要求され続ける。このような状況の中で, 曲げ加工によ り横断面が扁平・偏肉した銅配管の疲労破壊現象を解明 することは，製品の信頼性を損なうことなく低コスト化 を実現できる高精度な疲労設計技術の構築につながるた め, 重要であると考える.

本論文では，内圧作用下に打ける曲げ加工された銅配 管の疲労破壊現象を解明した内容について報告する。ま ず，曲げ加工された銅配管の内圧疲労試験を実施し，つ ぎに，その疲労破壊状況扎よび扁平・偏肉した横断面の 応力状態について検討した。最後に, これら試験結果お よび検討結果を考察して，曲げ加工された銅配管の内圧 疲労破壊現象を解明した。

\section{2 曲げ加工された銅配管の内圧疲労試験結果}

\section{$2 \cdot 1$ 内圧疲労試験方法と銅配管試験片}

本検討で使用した内圧疲労試験装置を Fig. 1 に示す. 本装置は, 電気油圧サーボ式疲労試験機のアクチュエー タ部に設置された油圧シリンダーを用いて，銅配管試験 片に内圧負荷を繰返し作用させる装置である。作用圧力 の設定は，銅配管試験片の出口側に設置された圧力セン サーをモニターすることによって実施した。試験結果と して得られる疲労寿命は, 油の漏洩による圧力低下が生

$\dagger$ 原稿受理 平成 23 年 9 月 5 日 Received Sep. 5, 2011 @ 2012 The Society of Materials Science, Japan

* 正 会 員 三菱電機株先端技術総合研究所 ＝661-8661 尼崎市塚口本町, Advanced Tech. R \& D Center, Mitsubishi Electric Corp., Tsukaguchi-honmachi, Amagasaki, 661-8661 


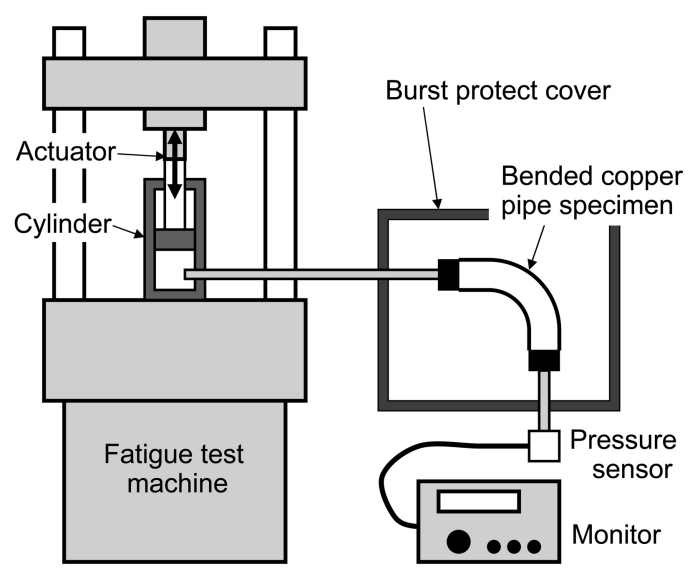

Fig. 1 Internal pressurized fatigue test machine.

じた時点の負荷繰返し数とした。なお本試験装置には， 銅配管試験片が破裂飛散するのを防止するためのカバー を, 安全のために設置している.

銅配管試験片の寸法を Table 1 に示す。試験に供し た銅配管試験片は Type A および B の 2 種類である. Table 1 の $D_{o}$ は配管外直径， $D_{i}$ は配管内直径， $T$ は配 管厚さ， $R_{m}$ および $\theta$ は，曲げ加工時の曲げ曲率半径お よび曲げ角度をそれぞれ示している。ここで， $D_{o}, D_{i}$, $T$ は実測值ではなく公称值である。また， $R_{m} / D_{o}$ は曲げ 曲率半径と配管外直径の比であり， $R_{m} / D_{o}$ が小さいほど 曲げ変形が大きいことを示している。なお，本試験で採 用した銅配管試験片の材料は，空調機や給湯機の冷媒配 管材として一般的に使用されているりん脱酸銅である.

\section{$2 \cdot 2$ 内圧疲労試験結果}

Type A およびBの内压疲労試験結果を Table 2 に示 す。疲労試験を実施した環境は大気中で，温度は室温で ある. Table 2 の $\Delta P$ は作用内圧範囲， $R$ は応力比 $(R=$ $\left.\sigma_{\min } / \sigma_{\max }\right)$ および $N_{f}$ は疲労寿命である.内圧疲労試験で は，製品寿命（10 $\sim 10^{5}$ 回範囲）の疲労曲線が得られる ように $\Delta P$ を設定した。 また, Table 2 の $\Delta \sigma$ は式 (1)に示 す Lamé の式で算出した厚肉円筒（真円）における内周 側円周方向の弾性応力範囲である。

$$
\Delta \sigma=\frac{D_{o}^{2}+D_{i}^{2}}{D_{o}^{2}-D_{i}^{2}} \Delta P
$$

Type A および B の銅配管試験片は $D_{o} / D_{i}=1.20$ および 1.34 であり，ともに薄肉円筒であるとは言い難いので，弾 性応力の計算には式 (1)を用いた。 なお，Table 2のT.P. No. B-4の $N_{f}$ に付記した>印は，未破壊データであるこ とを示している.

Fig. 2 は, Table 2 の内圧疲労試験結果を $\Delta \sigma-N_{f}$ 線図

Table 1 Size of bended copper pipe specimens.

\begin{tabular}{|c|c|c|c|c|c|c|}
\hline $\begin{array}{c}\text { T.P. } \\
\text { type }\end{array}$ & $\begin{array}{c}D_{o} \\
(\mathrm{~mm})\end{array}$ & $\begin{array}{c}D_{i} \\
(\mathrm{~mm})\end{array}$ & $\begin{array}{c}T \\
(\mathrm{~mm})\end{array}$ & $\begin{array}{c}R_{m} \\
(\mathrm{~mm})\end{array}$ & $\begin{array}{c}\theta \\
(\mathrm{deg})\end{array}$ & $R_{m} / D_{o}$ \\
\hline $\mathrm{A}$ & 9.52 & 7.92 & 0.8 & 20.0 & 90 & 2.10 \\
\hline $\mathrm{B}$ & 15.88 & 11.88 & 2.0 & 50.0 & 180 & 3.15 \\
\hline
\end{tabular}

$D_{o}$ : Outer dia., $D_{i}$ : Inner dia., $T$ : Thickness,

$R_{m}$ : Radius of bent curvature, $\theta$ : Angle of bent curvature.
Table 2 Fatigue test results of bended copper pipe specimens under internal pressure.

\begin{tabular}{|c|c|c|c|c|c|}
\hline $\begin{array}{c}\text { T.P. } \\
\text { type }\end{array}$ & $\begin{array}{c}\text { T.P. } \\
\text { No. }\end{array}$ & $\begin{array}{c}\Delta P \\
(\mathrm{MPa})\end{array}$ & $\begin{array}{c}\Delta \sigma \\
(\mathrm{MPa})\end{array}$ & $R$ & $\begin{array}{c}N_{f} \\
\text { (cycles) }\end{array}$ \\
\hline \multirow{4}{*}{ A } & $\mathrm{A}-1$ & 19.0 & 104 & 0.050 & $2.47 \times 10^{4}$ \\
\cline { 2 - 6 } & $\mathrm{A}-2$ & 17.0 & 93.4 & 0.056 & $2.87 \times 10^{4}$ \\
\cline { 2 - 6 } & $\mathrm{A}-3$ & 22.0 & 121 & 0.043 & $2.21 \times 10^{4}$ \\
\cline { 2 - 6 } & $\mathrm{A}-4$ & 25.0 & 137 & 0.038 & $9.20 \times 10^{3}$ \\
\cline { 2 - 6 } & $\mathrm{A}-5$ & 14.0 & 76.9 & 0.067 & $9.82 \times 10^{4}$ \\
\hline \multirow{4}{*}{$\mathrm{B}$} & $\mathrm{B}-1$ & 44.0 & 156 & 0.011 & $1.86 \times 10^{5}$ \\
\cline { 2 - 6 } & $\mathrm{B}-2$ & 58.0 & 205 & 0.009 & $2.16 \times 10^{4}$ \\
\cline { 2 - 6 } & $\mathrm{B}-3$ & 39.0 & 138 & 0.013 & $2.08 \times 10^{5}$ \\
\cline { 2 - 6 } & $\mathrm{B}-4$ & 37.0 & 131 & 0.013 & $>4.00 \times 10^{5 \%}$ \\
\hline
\end{tabular}

$\Delta P:$ Internal pressure range,

$\Delta \sigma$ : Elastic stress range of Lamé's equation,

$R:$ Stress $\operatorname{ratio}\left(R=\sigma_{\min } / \sigma_{\max }\right), \quad N_{f}:$ Fatigue life,

※ Mark " $>$ " is expressed "non-failure".

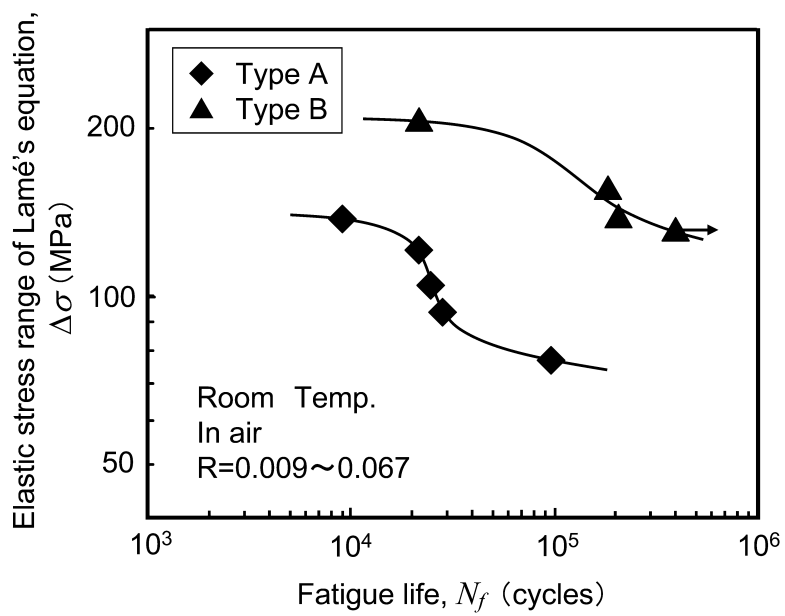

Fig. $2 \Delta \sigma-N_{f}$ diagram of fatigue test results.

で表示した図である，銅配管には，降伏応力を超える弾 塑性応力が発生していると思われるが，ここでは，設計

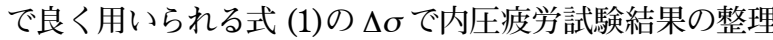
を試みた. Fig. 2 では, Type A と B の疲労強度は大き く異なっていた，弾塑性応力での検討がなされていない が，設計で良く用いられる $\Delta \sigma て ゙ ，$ 曲げ加工された銅配管 の内圧疲労試験結果を整理することはできないとわかる.

\section{$2 \cdot 3$ 疲労破壊状況および扁平・偏肉状況の観察}

銅配管試験片の疲労破壊状況写真（一例）を Fig. 3 に示す. Fig. 3 の(a)扎よび(b)は，それぞれ Type A (T.P. No. A-3) およびType B (T.P. No. B-1) の疲労破壊 状況写真である。ここで，各配管試験片の横断面写真は 疲労き裂が確認された位置における切断面を撮影したも のである。これらの横断面写真では，曲げ加工による扁 平・偏肉が確認できる。 また，横断面の形状はだ円とい うより団扇のような形状をしていた．曲げ加工された配 管の横断面が，だ円ではなく団扇のような形状に変形す

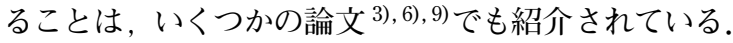

Fig. 3 の横断面写真において, 曲げ曲率半径 $R_{m}$ の外 側をOuter 部，内側を Inner 部および側面をSide 部とし た. T.P. No. A-3 の疲労き裂は, Outer 部の配管外側で 


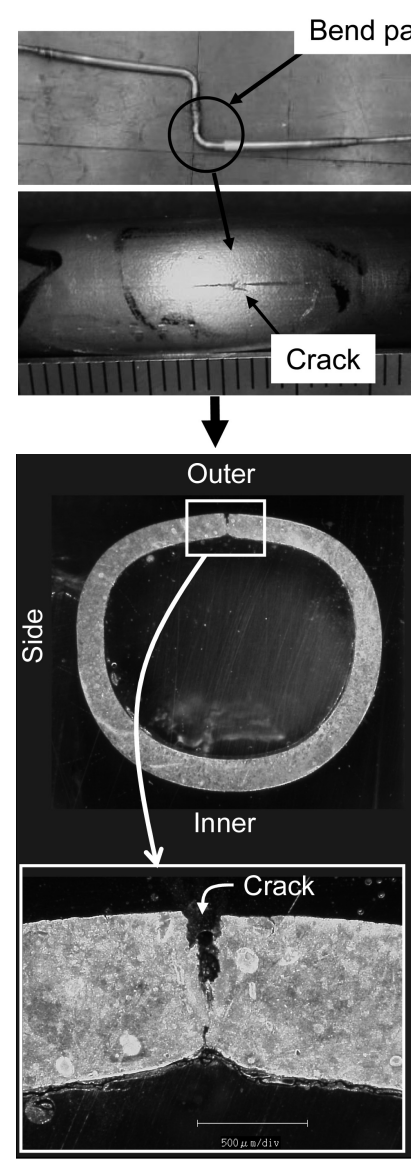

(a) Type A (T.P. No.A-3)

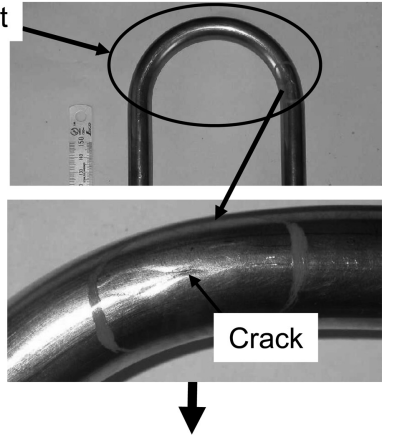

Outer

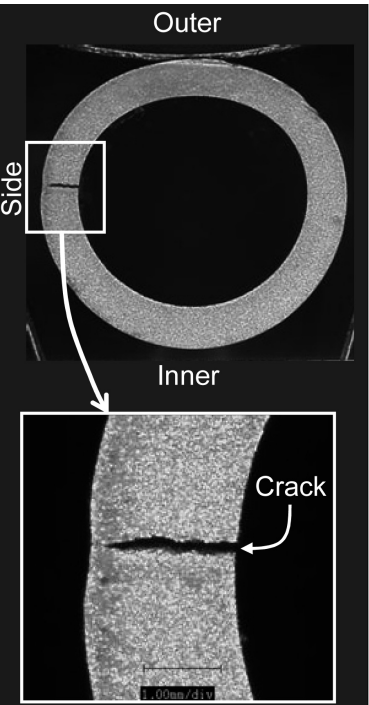

(b) Type B (T.P. No.B-1)
Fig. 3 Fatigue fracture photograph of bended copper pipe specimens (Type $\mathrm{A}$ and $\mathrm{B}$ ).

発生し，配管内側へと進展しているように見える。また， T.P. No. B-1 の疲労き裂は, Side 部の配管内側で発生し， 配管外側へと進展しているように見える。このようなき裂 の発生および進展の様相は, Type A および B の他の銅配 管試験片に打いても，それぞれ同様であった。 Type A 打 よび $\mathrm{B}$ は，疲労強度だけでなくき裂の発生位置と進展方 向も異なっていた。な打, Fig. 3 に打いて, き裂は開口量 の大きい方から小さい方へ進展したと判断した.

次に, 銅配管試験片の破壊位置横断面に打ける扁平率 $\left(D_{o S} / D_{o L}\right)$ と偏肉率 $\left(T_{o u t} / T_{\text {in }}\right)$ を測定した結果を Table 3 に示す．ここで, $D_{o S}$ は扁平断面の短軸配管外直径, $D_{o L}$ は長軸配管外直径, $T_{\text {out }}$ は Outer 部の配管厚さおよび $T_{\text {in }}$ は Inner 部の配管厚さである。これら $D_{o S}, D_{o L}, T_{\text {out }}$ お よび $T_{\text {in }}$ は Fig. 4 で図説していると打りである. 扁平率 は 1 に近いほど真円に近く, 偏肉率も 1 に近いほど偏肉 が小さいことを示している。なお，未破壊であったT.P. No. B-4 の扁平率と偏肉率は曲げ加工部の中央部分 （Fig. 4 の A-A 部）で切断した配管横断面の寸法を採用 した.

Fig. 5 は, $R_{m} / D_{o}$ と $D_{o S} / D_{o L}$ の関係打よび $R_{m} / D_{o}$ と $T_{\text {out }} / T_{\text {in }}$ の関係を示した罒である. $R_{m} / D_{o}$ が小さいほど 曲げ変形が大きくなるので, $D_{o s} / D_{o L}$ 扩よび $T_{\text {out }} / T_{\text {in }}$ は共 に 1 に対して小さくなって打り, 扁平・偏肉による横断 面の変形が顕著となっていることがわかる.
Table 3 Measurement results of flattening ratio $\left(D_{o S} / D_{o L}\right)$ and change in thickness ratio $\left(T_{\text {out }} / T_{\text {in }}\right)$ of bended copper pipe specimens.

\begin{tabular}{|c|c|c|c|}
\hline $\begin{array}{c}\text { T.P. } \\
\text { type }\end{array}$ & $\begin{array}{c}\text { T.P. } \\
\text { No. }\end{array}$ & $D_{o S} / D_{\text {oL }}$ & $T_{\text {out }} / T_{\text {in }}$ \\
\hline \multirow{4}{*}{ A } & A-1 & 0.874 & 0.691 \\
\cline { 2 - 4 } & A-2 & 0.853 & 0.750 \\
\cline { 2 - 4 } & A-3 & 0.916 & 0.750 \\
\cline { 2 - 4 } & $\mathrm{A}-4$ & 0.915 & 0.617 \\
\cline { 2 - 4 } & $\mathrm{A}-5$ & 0.842 & 0.682 \\
\hline \multirow{4}{*}{ B } & B-1 & 0.917 & 0.874 \\
\cline { 2 - 4 } & B-2 & 0.943 & 0.813 \\
\cline { 2 - 4 } & B-3 & 0.922 & 0.816 \\
\cline { 2 - 4 } & B-4 & 0.929 & 0.878 \\
\hline
\end{tabular}

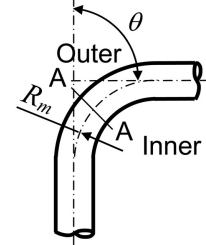

Type A

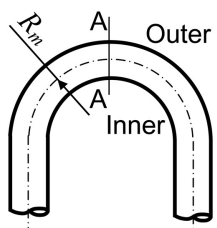

Type B

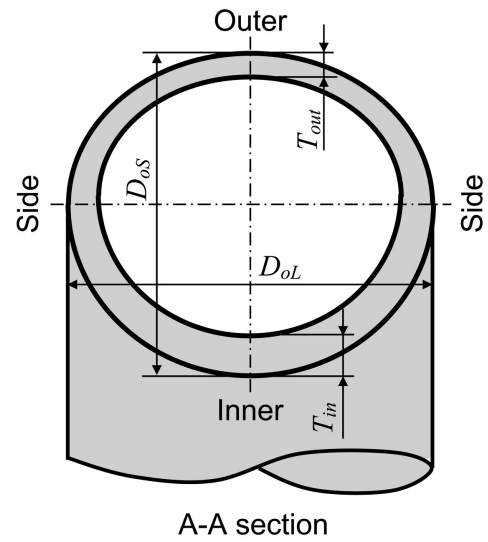

A-A section

Fig. 4 Illustration of cross section of bended copper pipe specimens.

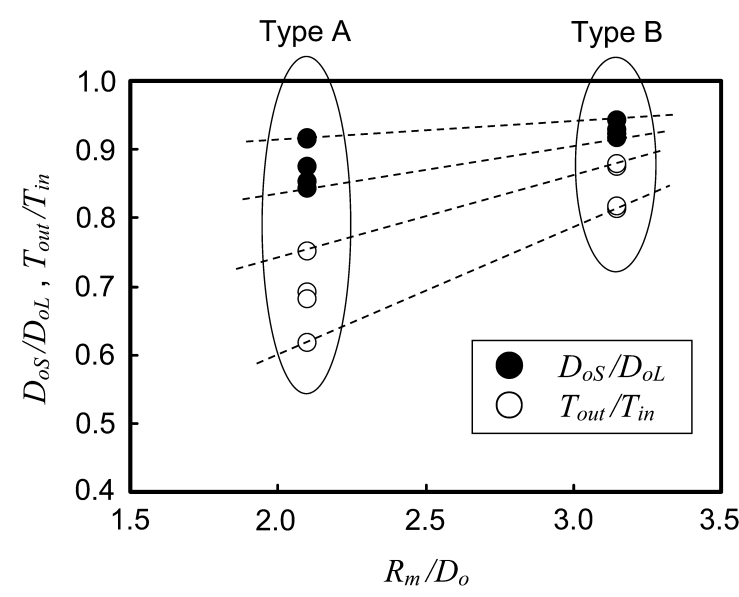

Fig. 5 Correlation between $R_{m} / D_{o}$ and $D_{o s} / D_{o L}$, and correlation between $R_{m} / D_{o}$ and $T_{\text {out }} / T_{\text {in }}$.

\section{3 曲げ加工された銅配管試験片横断面の} 有限要素法による弾性応力計算結果

疲労破壊した銅配管試験片の横断面における形状寸法 を詳細に測定し，有限要素法 (FEM) を用いて，内圧作 用時の弾性応力計算を実施した。計算結果である最大主 応力分布図の一例を Fig. 6 に示す。ここで, Fig. 6 の(a) および(b)は，それでれT.P. No. A-3 およびT.P. No. B-1 の応力分布図である。作用内圧範囲は，T.P. No. A-3 の 


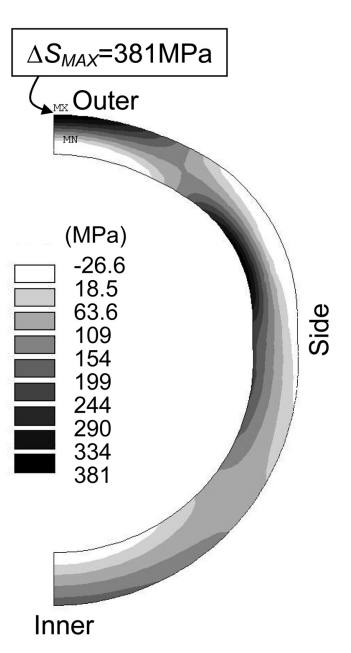

(a) T.P. No.A-3

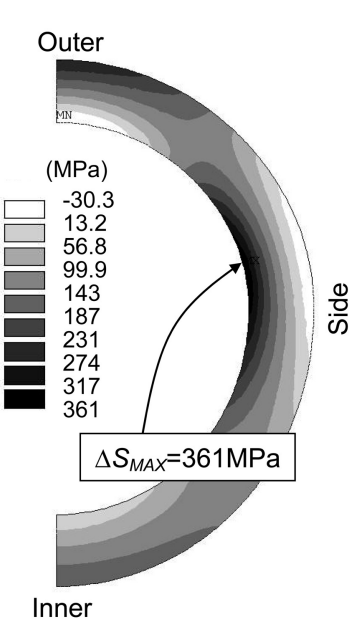

(b) T.P. No.B-1
Fig. 6 Stress conditions (distribution of maximum principal stress) in cross section of bended copper pipe specimens calculated by FEM.

場合 $\Delta P=22.0 \mathrm{MPa}$, T.P. No. B-1 の場合 $\Delta P=44.0 \mathrm{MPa}$ であり, 疲労試験と同じ内圧範囲を作用（Table 2 参照） させて FEM 弾性応力計算を実施した。な ルは，2 次元平面ひずみ要素を使用し，1/2 対称で作成 した。使用した構造解析プログラムは ANSYS Ver.12で ある。

Fig. 6 の結果から, 最大值 $\Delta S_{M A X}$ の発生位置は, T.P. No. A-3 の場合 Outer 部の配管外側であり, T.P. No. B-1 の場合 Side 部の配管内側であった。これら $\Delta S_{M A X}$ の発 生位置と Fig. 3 で示した疲労試験結果のき裂発生位置 は一致していた。また， $\Delta S_{M A X}$ 発生位置の配管厚さ方向 の応力分布は応力集中部のような分布を呈していた.

Table 4 は, $D_{o S} / D_{o L}, T_{\text {out }} / T_{\text {in }}, \mathrm{FEM}$ 弾性応力計算結 果の最大值 $\Delta S_{M A X}$ および $\Delta S_{M A X}$ と式 (1)の $\Delta \sigma$ の比 $\left(\Delta S_{M A X} / \Delta \sigma\right)$ の值をそれぞれ示した表である. また Fig. 7 は, Table 4 の值を用いて $\Delta S_{M A X} / \Delta \sigma$ と $D_{o S} / D_{o L}$ の関係 および $\Delta S_{M A X} / \Delta \sigma$ と $T_{\text {out }} / T_{\text {in }}$ の関係を示した図である. $D_{o S} / D_{o L}=1$ (真円) かつ $T_{o u t} / T_{i n}=1$ (編肉なし) で, $\Delta S_{M A X}$ は $\Delta \sigma$ に等しくなるので，扁平および編肉が $\Delta S_{M A X}$ に及ぼす影響を表す指標として $\Delta S_{M A X} / \Delta \sigma$ を採用した。

Fig. 7 (a)では, Type A およびBのそれぞれにおいて,

Table $4 D_{o S} / D_{o L}, T_{\text {out }} / T_{\text {in }}, \Delta S_{M A X}$ and $\Delta S_{M A X} / \Delta \sigma$ of bended copper pipe specimens.

\begin{tabular}{|c|c|c|c|c|c|}
\hline $\begin{array}{c}\text { T.P. } \\
\text { type }\end{array}$ & $\begin{array}{c}\text { T.P. } \\
\text { No. }\end{array}$ & $\frac{D_{\text {oS }}}{D_{\text {oL }}}$ & $\frac{T_{\text {out }}}{T_{\text {in }}}$ & $\begin{array}{c}\Delta S_{\text {MAX }} \\
(\mathrm{MPa})\end{array}$ & $\frac{\Delta S_{\text {MAX }}}{\Delta \sigma}$ \\
\hline \multirow{4}{*}{ A } & $\mathrm{A}-1$ & 0.874 & 0.691 & 437 & 4.18 \\
\cline { 2 - 6 } & $\mathrm{A}-2$ & 0.853 & 0.750 & 432 & 4.62 \\
\cline { 2 - 6 } & $\mathrm{A}-3$ & 0.916 & 0.750 & 381 & 3.15 \\
\cline { 2 - 6 } & $\mathrm{A}-4$ & 0.915 & 0.617 & 468 & 3.41 \\
\cline { 2 - 6 } & $\mathrm{A}-5$ & 0.842 & 0.682 & 377 & 4.90 \\
\hline \multirow{4}{*}{ B } & $\mathrm{B}-1$ & 0.917 & 0.874 & 361 & 2.32 \\
\cline { 2 - 6 } & $\mathrm{B}-2$ & 0.943 & 0.813 & 415 & 2.02 \\
\cline { 2 - 6 } & $\mathrm{B}-3$ & 0.922 & 0.816 & 305 & 2.21 \\
\cline { 2 - 6 } & $\mathrm{B}-4$ & 0.929 & 0.878 & 276 & 2.10 \\
\hline
\end{tabular}

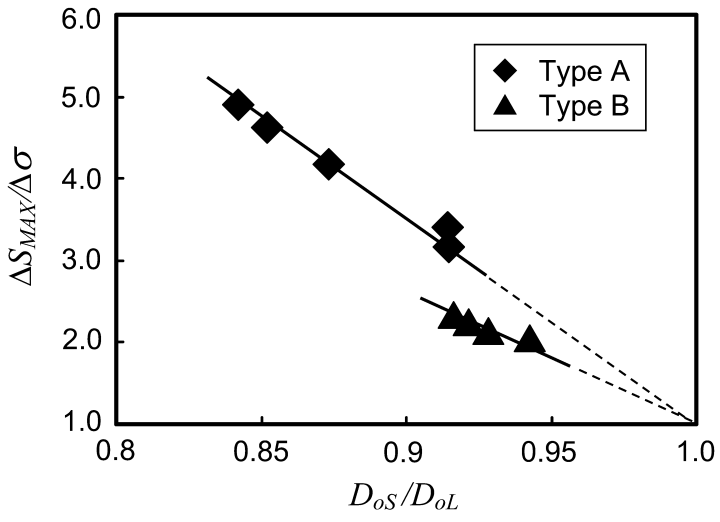

(a) Correlation between $\Delta S_{M A X} / \Delta \sigma$ and $D_{o S} / D_{o L}$.

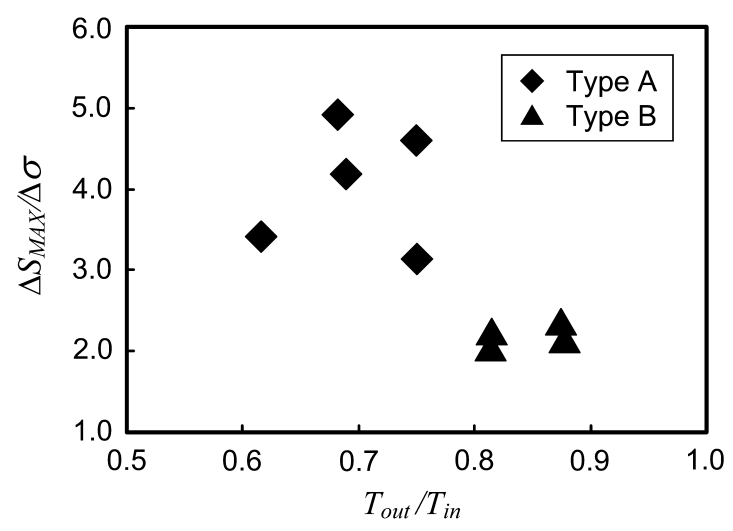

(b) Correlation between $\Delta S_{M A X} / \Delta \sigma$ and $T_{\text {out }} / T_{\text {in }}$.

Fig. 7 Correlation between $\Delta S_{M A X} / \Delta \sigma D_{o S} / D_{o L}$, and correlation between $\Delta S_{M A X} / \Delta \sigma$ and $T_{\text {out }} / T_{\text {in }}$.

$\Delta S_{M A X} / \Delta \sigma$ と $D_{o S} / D_{o L}$ は強い相関関係にあり，なおかつ $D_{o S} / D_{o L}$ が 1 (真円) に近づくと，それぞれの $\Delta S_{M A X} / \Delta \sigma$ も 1 に近づいていく傾向を示していた. 次に, Fig. 7 (b) では, Type AおよびBのそれぞれにおいて， $\Delta S_{M A X} / \Delta \sigma$ と $T_{\text {out }} / T_{\text {in }}$ の相関関係は見られなかった. しかし, 編肉の 大きい $\left(T_{\text {out }} / T_{\text {in }}\right.$ の小さい) Type $\mathrm{A} の \Delta S_{M A X} / \Delta \sigma$ の值は 大きく, 編肉の小さい $\left(T_{\text {out }} / T_{\text {in }}\right.$ の大きい) $\Delta S_{M A X} / \Delta \sigma$ の 值は小さい結果となっていた. Fig. 7 (a)で, $\Delta S_{M A X} / \Delta \sigma$ と $D_{o S} / D_{o L}$ の関係が Type A と B でそれぞれ 2 本の線に 別れていたのは，編肉が影響しているのか， $\triangle S_{M A X}$ 発生 位置の違いが影響しているのか，今回試験した範囲では 良くわからなかった。

これらの検討は，断面を切断することなく外観寸法と $\Delta \sigma$ だけで $\Delta S_{M A X}$ を推定するときに必要となる. 今後, こ のようなデータを増やしていくことで, $\Delta S_{M A X} / \Delta \sigma$ と $D_{o S} /$ $D_{o L}$ および $T_{\text {out }} / T_{\text {in }}$ の関係を解明していきたいと考える.

\section{4 曲げ加工された銅配管の疲労破壊現象 についての考察}

応力集中部の疲労寿命は，その応力集中部に作用する 弾塑性ひずみと丸棒平滑試験片の全ひずみ振幅一疲労寿 命曲線（ $\varepsilon_{t a}-N_{f}$ 曲線）を対比させて予測することができ る.ここで, 構造全体が弾性挙動をしていた場合, 応力 集中部に作用する弾塑性ひずみは Neuber 則 ${ }^{10)}$ を用いて, 当該部の弾性最大応力から見積もることができる. 
Fig. 6 の FEM 結果から， $\Delta S_{M A X}$ 発生位置の配管厚さ 方向の応力分布は応力集中部的な分布様相をしていた. また，疲労破壊後の配管断面（Fig. 3 参照）が扁平形状 を保っていたことから, 疲労試験の内圧負荷下において も，配管断面はある程度の弾性変形内であったと予想で きる．よって本章では，応力集中部における Neuber 則 を用いた低サイクル疲労評価の考え方に基づいて，Type $\mathrm{A}$ および B の内圧疲労試験結果の整理を試みる.

銅配管材料であるりん脱酸銅 (phosphorous-deoxidized copper) の機械的性質 ${ }^{11)}$ table 5 に示す。ここ で， $\sigma_{0.2}$ は引張試験で得られる静的 $0.2 \%$ 而力， $\sigma_{B}$ は引張 強さ, $\delta$ は破断伸び, $\phi$ は絞り, $\varepsilon_{f}$ は真破断延性, $E$ は縦 弾性係数および $v_{e}$ は弾性ポアソン比である。 また,りん 脱酸銅の低サイクル疲労試験結果 ${ }^{11)}$ を Fig. 8 に示す. Fig. 8 の実線は，式 (2)に示す Basquin \& Coffin-Manson 型の $\varepsilon_{t a}-N_{f}$ 曲線で, 疲労データを近似した線である。

$$
\begin{aligned}
\varepsilon_{t a} & =\frac{C_{e}}{2} N_{f}^{-k e}+\frac{C_{p}}{2} N_{f}^{-k p} \\
& =0.00243 N_{f}^{-0.0829}+0.370 N_{f}^{-0.519}
\end{aligned}
$$

式 (2)において, $C_{e}$ は疲労強度係数, $k_{e}$ は疲労強度指数, $C_{p}$ は疲労延性係数打よび $k_{p}$ は疲労延性指数である。な お，機械的性質および低サイクル疲労試験結果は, 丸棒 平滑試験片で採取した結果である.

つぎに, Ramberg-Osgood 型の繰返し応力ーひずみ曲 線（CSS 曲線）を，式 (2)の $C_{e}, k_{e}, C_{p}$ および $k_{p}$ の值を 用いて，式 (3)のように表示 ${ }^{12)} し た 。$ 式 (3)は, Neuber 則 を用いて応力集中部の弾性最大応力から弾塑性ひずみを 見積もるときに必要な式である。

Table 5 Mechanical properties of phosphorous-deoxidized copper. ${ }^{11)}$

\begin{tabular}{|c|c|c|c|c|c|c|}
\hline $\begin{array}{c}\sigma_{0.2} \\
(\mathrm{MPa})\end{array}$ & $\begin{array}{c}\sigma_{B} \\
(\mathrm{MPa})\end{array}$ & $\begin{array}{c}\delta \\
(\%)\end{array}$ & $\begin{array}{c}\phi \\
(\%)\end{array}$ & $\varepsilon_{f}$ & $\begin{array}{c}E \\
(\mathrm{MPa})\end{array}$ & $v_{e}$ \\
\hline 36.2 & 225 & 56.0 & 88.0 & 2.12 & 129000 & 0.313 \\
\hline
\end{tabular}

$\sigma_{0.2}$ : Static $0.2 \%$ proof stress, $\sigma_{B}$ : Tensile strength, $\delta$ : Elongation, $\phi$ : Reduction of area, $\varepsilon_{f}$ : True fracture ductility, $E$ : Modulus of elasticity, $v_{e}$ : Elastic Poisson's ratio.

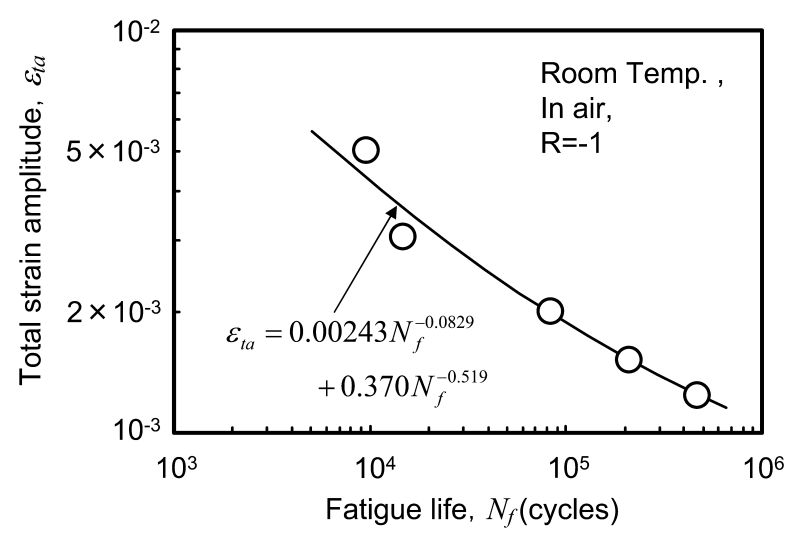

Fig. 8 Low-cycle fatigue test results of phosphorousdeoxidized copper. ${ }^{11)}$
Table 6 Estimation results of elastic-plastic strain amplitude from $\triangle S_{M A X}$ obtained by Neuber's rule.

\begin{tabular}{|c|c|c|c|c|}
\hline $\begin{array}{c}\text { T.P. } \\
\text { type }\end{array}$ & $\begin{array}{c}\text { T.P. } \\
\text { No. }\end{array}$ & $\begin{array}{c}\Delta S_{M A X} \\
(\mathrm{MPa})\end{array}$ & $\varepsilon_{t a}$ & $\begin{array}{c}N_{f} \\
\text { (cycles) }\end{array}$ \\
\hline \multirow{4}{*}{ A } & $\mathrm{A}-1$ & 437 & $2.78 \times 10^{-3}$ & $2.47 \times 10^{4}$ \\
\cline { 2 - 5 } & $\mathrm{A}-2$ & 432 & $2.73 \times 10^{-3}$ & $2.87 \times 10^{4}$ \\
\cline { 2 - 5 } & $\mathrm{A}-3$ & 381 & $2.23 \times 10^{-3}$ & $2.21 \times 10^{4}$ \\
\cline { 2 - 5 } & $\mathrm{A}-4$ & 468 & $3.11 \times 10^{-3}$ & $9.20 \times 10^{3}$ \\
\cline { 2 - 5 } & $\mathrm{A}-5$ & 377 & $2.19 \times 10^{-3}$ & $9.82 \times 10^{4}$ \\
\hline \multirow{4}{*}{$\mathrm{B}$} & $\mathrm{B}-1$ & 361 & $2.04 \times 10^{-3}$ & $1.86 \times 10^{5}$ \\
\cline { 2 - 5 } & $\mathrm{B}-2$ & 415 & $2.55 \times 10^{-3}$ & $2.16 \times 10^{4}$ \\
\cline { 2 - 5 } & $\mathrm{B}-3$ & 305 & $1.57 \times 10^{-3}$ & $2.08 \times 10^{5}$ \\
\cline { 2 - 5 } & $\mathrm{B}-4$ & 276 & $1.35 \times 10^{-3}$ & $>4.00 \times 10^{5 \%}$ \\
\hline
\end{tabular}

$\Delta S_{M A X}$ : Maximum stress range,

$\varepsilon_{t a}$ : Elastic-plastic strain amplitude obtained by Neuber's rule, $N_{f}$ : Fatigue life,

$※$ Mark ">" is expressed "non-failure".

$$
\varepsilon_{t a}=\frac{\sigma_{a}}{E}+\frac{C_{p}}{2}\left(\frac{2 \sigma_{a}}{C_{e} E}\right)^{\frac{k p}{k e}}=\frac{\sigma_{a}}{129000}+\left(\frac{\sigma_{a}}{367}\right)^{6.26}
$$

Neuber 則を用いて，弾性最大応力 $\triangle S_{M A X}$ から見積っ た弾塑性ひずみ振幅 $\varepsilon_{t a}$ の值を Table 6 に示す. Table 2 で示した内圧疲労試験結果は, 応力比 $R$ が 0.009 0.067 であり，ほぼ片振りに近い応力状態であった。し かし， $\Delta S_{M A X}$ の值が式 (3)の塑性項より得られる動的 $0.2 \%$ 耐力 $\left(\sigma_{0.2 d}\right)$ の 2 倍以上であったので, $\Delta S_{M A X}$ 発生 位置における応力とひずみの挙動がヒステリシスループ を描く両振り状態になると仮定して $\varepsilon_{t a}$ を求めた。ここ で，式 (3)の塑性項より得られる $\sigma_{0.2 d}$ の值は式 (4)に示 すとおりである.

$$
\sigma_{0.2 d}=(0.002)^{1 / 6.26} \times 367=136 \mathrm{MPa}
$$

Neuber則による,$\varepsilon_{t a}$ の見積り值は，式 (3)と以下の 式 (5)の連立方程式を解くことによって求められる。こ こで, 式 (5)の $S_{a}$ は $\Delta S_{M A X}$ の半分の值 $\left(\Delta S_{M A X} / 2\right)$ であ り既知量である。

$$
\sigma_{a} \varepsilon_{t a}=\frac{S_{a}^{2}}{E}=\frac{S_{a}^{2}}{129000}
$$

なお，式 (3)と(5)の連立方程式から， $\varepsilon_{t a}$ を陽的に解くこ とができないので，本検討では Newton-Raphson 法を用 いて反復計算することにより， $\varepsilon_{t a}$ を算出した。 そのとき の収束条件は相対誤差 $\leqq 10^{-6}$ である.

Fig. 9 は, Table 6 の $\varepsilon_{t a}$ と $N_{f}$ の值と Fig. 8 のりん脱 酸銅を含む銅および銅合金の低サイクル疲労試験結果 ${ }^{11)}$ を比較した罒である. Type A および B の疲労試験結果 (けおよびム印) は, Fig. 8 で示したりん脱酸銅の低サ イクル疲労試験結果（○印）と概ね一致していた。また， 他の銅および銅合金の低サイクル疲労試験結果 ${ }^{11)}$ (+印) のばらつきの範囲内にあることもわかる。これより，曲 げ加工により横断面が扁平・偏肉した銅配管の内圧疲労 破壊現象は，応力集中部におけるひずみ制御型の低サイ クル疲労破壊現象と同様であると判断できる。 


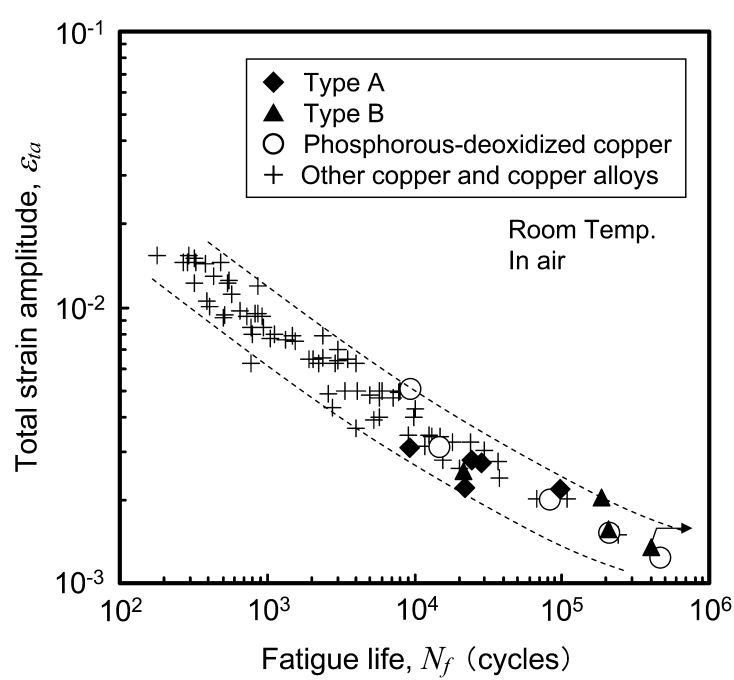

Fig. 9 Comparison of fatigue test results of bended copper pipe specimens (Type A and B) and low-cycle fatigue test results of copper and copper alloys.

\section{5 結言}

曲げ加工により横断面が扁平・偏肉した二種類の銅配 管の内圧疲労試験を実施し，これら銅配管の破壊状況や 扁平・偏肉した横断面の応力状態について検討した。そ の後, これらの試験結果と検討結果を考察して, 曲げ加 工された銅配管の内圧疲労破壊現象を解明した。

以下に結論を述べる。

(1) 曲げ加工された銅配管横断面の FEM 弾性応力計 算を実施した結果，その最大值 $\Delta S_{M A X}$ が発生した位置と 疲労き裂発生位置は一致していた。この $\Delta S_{M A X}$ 発生位置 が曲げ加工された銅配管の疲労破壊の起点であることを 確認した.

（2）今回試験に供した銅配管試験片に打いて， $\Delta S_{M A X} / \Delta \sigma$ は扁平率 $\left(D_{o S} / D_{o L}\right)$ の影響を強く受け，偏肉 率 $\left(T_{\text {out }} / T_{\text {in }}\right)$ の影響はあまり顕著でなかった。

(3) Neuber則を用いて， $\Delta S_{M A X}$ から弾塑性ひずみ振 幅 $\varepsilon_{t a}$ を見積もった。この $\varepsilon_{t a}$ と $N_{f}$ の值を銅および銅合金 の低サイクル疲労試験結果と比較したところ, 両者は概 ね一致していた。曲げ加工された銅配管の内圧疲労破壊 現象は，応力集中部におけるひずみ制御型の低サイクル 疲労破壊現象と同様であると判断できる.

\section{参 考 文 献}

1) T. Mimino and S. Murase, "Change in thickness at the bent part of U-type electric resistance welded steel tube and its strength against internal pressure”, Nihon Koukan Gihou, No.29, pp.28-40 (1964).

2 ) T. Murota and J. Endow, "Experimental analysis on plastic deformation of tubes in uniform bending", Journal of the JSTP, Vol.23, No.225, pp.343-350 (1982).

3 ) K. Takahashi, T. Watanabe, T. Kuboki, M. Murata, K. Ono and K. Yano, "Reduction in flatness using axial compressive force in rotary draw bending of circular tube”, Journal of the JSTP, Vol.49, No.572, pp.896-900 (2008).

4 ) K. Toyama, M. Yamamoto, S. Morimoto and T. Furumai, "Development of high strength electric-resistance-welded steel tubes for hydraulic system of earth moving machines", Sumitomo Kinzoku, Vol.40, No.3, pp.289-294 (1988).

$5)$ S. Ooshima, "A study on fatigue strength of thin copper tube”, REFRIGERATION, Vol.70, No.814, pp.858-869 (1995).

6 ) H. Suzuki and K. Takiuchi, "Fatigue reliability in terms of fatigue fracture under internal pressure of the tube used in brake equipment for automobiles", Transaction of the Japan Society of Mechanical Engineers, Series A, Vol.63, No.612, pp.1642-1647 (1997)

7 ) T. Hosogi, T. Choda and C. Saeki, "Cyclic pressure fatigue property of copper tube for air conditioner”, Journal of the JCBRA, Vol.40, No.1, pp.243-247 (2001).

8 ) H. Iijima, T. Enomoto and T. Kouda, "Recent heat pump technologies for energy saving”, MITSUBISHI, Vol.82, No.3, pp.174-178 (2008)

9) M. Yoshida and M. Kobayashi, "Prediction of the bend ability of copper tube by FEM simulation”, Journal of the JRICu, Vol.41, No.1, pp.54-58 (2002).

10) H. Neuber, "Theory of stress concentration for shear strained prismatical bodies with arbitrary nonlinear stress-strain law", Transaction of the American Society of Mechanical Engineers, Journal of Applied Mechanics, pp.544-550 (1961).

11) Y. Tamiya, "A validity of estimation methods of total strain-fatigue life curve about copper and copper alloys", Journal of the Society of Materials Science, Japan, Vol.60, No.9, pp.777-782 (2011).

12) Y. Tamiya and T. Wada, "A practical use of simplified fatigue life prediction method at stress concentration of metals", Journal of the Society of Materials Science, Japan, Vol.58, No.4, pp.311-316 (2009). 